\title{
The Impact of Customer Satisfaction with EWOM and Brand Equity on E-Commerce Purchase Intention in Indonesia Moderated by Culture
}

\author{
Angga Febrian ${ }^{1 *}$; Muhtad Fadly ${ }^{2}$ \\ ${ }^{1-2}$ Management Study Program, Faculty of Economic and Business, Universitas Teknokrat Indonesia \\ Jln. ZA. Pagar Alam No.9-11, Lampung 35132, Indonesia \\ 1'angga_febrian@teknokrat.ac.id; ${ }^{2}$ muhtadfadly@gmail.com
}

Received: $30^{\text {th }}$ April 2020/ Revised: $27^{\text {th }}$ July 2020/ Accepted: $14^{\text {th }}$ September 2020

How to Cite: Febrian, A., \& Fadly, M. (2021). The Impact of Customer Satisfaction with EWOM and Brand Equity on E-Commerce Purchase Intention in Indonesia Moderated by Culture. Binus Business Review, 12(1), 41-51. https://doi. org/10.21512/bbr.v12i1.6419

\begin{abstract}
The digital era, which increasingly becomes massive in people's lives, impacts the traditional sales methods. E-commerce companies compete in winning the competition to create superior customer value. An effective and efficient marketing strategy is needed that can influence customer purchase intention. The research focused on the effect of customer satisfaction, which created eWOM and increased brand equity on purchase intention by adding culture (collectivist culture) as the moderator variables. The research applied a quantitative approach. The data were obtained from 280 respondents selected by non-probability sampling. Respondents were customers who had already bought products through e-commerce in Indonesia. The questionnaire instrument was adopted based on theories from the previous researchers. The data used the Likert scale and were analyzed using the SmartPLS 3.0. The results state a significant relationship between the independent and dependent variables. All independent variables have a significant influence on the dependent variable. However, culture as the moderator variable cannot get significant results in the relationship between all the variables. It gets irrelevant results. Hence, the results show that the moderator variable is more appropriate as the independent variable. It can directly affect purchase intention. The research contributes to testing culture as the moderator variable that makes the independent variables generalize the findings.
\end{abstract}

Keywords: customer satisfaction, electronic word of mouth (eWOM), brand equity, e-commerce, purchase intention, collectivist culture

\section{INTRODUCTION}

Historically, the efforts made by the company have focused on customer satisfaction. It will impact customer involvement (engagement). The higher the satisfaction is, the more the customers will voluntarily help to spread information about the online shopping experience. It is commonly called electronic word of mouth (eWOM) (Thakur, 2019). It is a useful interpersonal communication tool. It is proven to affect other customers' purchase intentions. Therefore, proper management of eWOM is a significant issue in creating a brand in customers' minds (Zhang, Liang, \& Qi, 2021). Customers conduct it, such as discussing the quality and product reviews (Tandon, Aakash, \& Aggarwal, 2020). Because information of eWOM comes from direct customers, not from the companies, this communication is very influential on online shoppers because they are informal, exchange feedback, and give personal information. It is beneficial compared to formal communication (Hidayanto, Ovirza, Anggia, Budi, \& Phusavat, 2017). It has been recognized as one of the most influential resources in the information. It impacts customers because the easy and accessible information can significantly influence consumption decisions (Olmedilla, Martínez-Torres, \& Toral, 2019). It can also influence brand image and purchase intention in a company. Marketers can use 
online platforms to make customers quickly see and choose products (Krishnamurthy \& Kumar, 2018)

Online shopping refers to buying and selling products and services through the Internet in e-commerce (Turban, Whiteside, King, \& Outland, 2017). Indonesians are very familiar with the existence of e-commerce in online shopping. Some of Indonesia's largest e-commerce companies include Tokopedia, Shopee, Bukalapak, Lazada, Blibli, and JD.id (iPrice, 2020). The high competition between e-commerce companies demands the companies to create better customer value than their competitors. However, the existing culture in an area can affect marketing communications. The previous research shows that when managers formulate online advertising and brand strategies, they must consider each country's different cultural dimensions. The failure rate of an online strategy will be lower if more and more e-commerce companies know a country's cultural values (Valaei, Rezaei, Ismail, \& Oh, 2016).

Indonesian culture, which tends to be collectivist, causes differences in marketing communication styles compared to other countries (Haryanto, Moutinho, \& Coelho, 2016; Wijaya, Wahyudi, Kusuma, \& Sugianto, 2018). They perceive themselves as a part of other people and tend to follow social norms. It is different from individualist culture that is selfish and disregards others' opinions (Luo, Wu, Shi, \& Xu, 2014). The importance of using eWOM communication in influencing customers with collectivist culture can affect their purchase intention (Levy \& Gvili, 2020; Yan et al., 2016)

Customer satisfaction is the most critical issue for online and offline companies in increasing sales (Hult, Sharma, Morgeson, \& Zhang, 2019). It is an emotional response of approval when getting satisfactory results and as an alternative when getting dissatisfied results (Cheng, Gan, Imrie, \& Mansori, 2018). It is a task for marketers to realize between customers' perceptions with marketing methods that are interpreted in various ways. Success in a company's long-term competitiveness is closely related to customer satisfaction. There is a relationship between customer satisfaction with customer relations. In the traditional understanding of the product or customer perception in quality related to service, it can be broadened to three aspects: the perspective related to the competition must be added, the level of customer involvement must be considered, and the perception in quality must be differentiated based on changes in customers' internal expectation standards (HennigThurau \& Klee, 1997).

In measuring the performance of eWOM, the researchers can use several indicators such as information quality, trustworthiness, loyalty, satisfaction, social relations, source quality, a quantity of information, and subjective norms (Sijoria, Mukherjee, \& Datta, 2019). The previous research shows that the characteristics of information, consumer behavior, and technological factors positively influence purchase intentions. The involvement of eWOM also has a significant effect. The eWOM involvement has a significant positive effect on purchase intentions. However, not all measured indicators have positive impacts, such as information quality and social support (Yusuf, Che Hussin, \& Busalim, 2018).

When the customers are satisfied, they will consciously intend to share the information regarding the product ( $\mathrm{Fu}, \mathrm{Ju}, \& \mathrm{Hsu}, 2015)$. The existence of eWOM communication conducted by customers based on their experience can shape the brand image (Sijoria et al., 2019). However, in practice, eWOM communication does not always go according to what is desired by the company, namely, the occurrence of positive eWOM. Negative eWOM can also occur when customers' expectations do not match the reality in the form of received goods or services. The frustrated consumer behavior leads to negative eWOM associated with reduced purchases and decreased trust in the brand (Azemi, Ozuem, \& Howell, 2020). Companies must anticipate the negative eWOM by quickly responding to these customers (Lee, Rodgers, $\&$ Kim, 2009). Then, the researchers propose the following hypothesis:

H1 : Customer satisfaction has a significant effect on eWOM

\section{H2 : EWOM has a significant effect on brand equity}

Companies must provide relevant information, content, and website design to attract attention to build positive eWOM. When the positive eWOM occurs, it means that the customers are satisfied with their experience. Then, it will lead to the purchase intention of those customers to repurchase or someone else who sees the eWOM distribution (Aslam, Farhat, $\&$ Arif, 2019). The eWOM has a positive effect on repurchase intentions and perceived value. At the same time, eWOM negatively affects perceived risk. The customers tend to look for information directly from experiences that match what they want to buy (Liang, Choi, \& Joppe, 2018). When the proportion of negative online reviews increases, it will affect the customers' attitudes in choosing a product. However, not all products, such as popular products, are influenced by negative reviews. Otherwise, an unpopular product will decrease purchase intentions (Shihab \& Putri, 2019). Companies must encourage customers to spread eWOM positively through excellent products and services (Ismagilova, Slade, Rana, \& Dwivedi, 2020). Hence, the proposed hypotheses are:

H3 : Customer satisfaction has a significant effect on purchase intentions

H4 : EWOM has a significant effect on purchase intentions

The increasing competition requires a unique feature that must be displayed differently to be a special attraction. It is called brand equity. It is an added value given to a product by considering customers' 
thoughts, words, and actions (Keller \& Brexendorf, 2019). Companies can build their products and services by connecting brands with other entities so customers can feel and act in thinking about brands (Keller, 2020). Five factors in brand equity are brand loyalty, brand awareness, brand quality perception, brand associations, and other exclusive brand assets. Customer trust in the excellent brand in the form of good service, customer satisfaction, and the reputation of the e-commerce company will influence purchase intentions (Oliveira, Alhinho, Rita, \& Dhillon, 2017).

Moreover, e-commerce platforms are essential because they contain information about products, brands, and services that meet customers' needs (Al-Dwairi, Harb, \& Shehabat, 2020). Marketing in e-commerce depends on how marketers can measure customer satisfaction that can affect brand equity (Nasiruddin \& Hashim, 2015). Brand equity becomes essential because it can influence positive attitudes that can manifest in consumer behavior, such as purchase intentions (Bae, Jung, Moorhouse, Suh, \& Kwon, 2020; Civelek \& Ertemel, 2019).

In studying consumer behavior, some researchers use the Theory of Planned Behavior in predicting someone's purchase intention. It is assumed that intention can influence behavior. The more influential the intention is, the more likely a person will do it (Amaro \& Duarte, 2015). Attitudes, subjective norms, and behavior control are used in measuring intentions in the Theory of Planned Behavior (Ajzen, 1985). Trust in the brand is believed to affect purchase intentions positively. It ultimately positively impacts buying behavior. Then, the researchers propose the next hypothesis as follows:

\section{H5 : Brand equity has a significant effect on purchase intentions}

Although previous studies have shown the results of eWOM and brand equity affect purchase intentions (Alrwashdeh, Emeagwali, \& Aljuhmani, 2019; Febrian \& Vinahapsari, 2020), they cannot be generalized when applying the method in a crosscultural manner. Many previous studies have examined the direct effect of eWOM on purchase intentions and must see the effects of moderation comprehensively (Ismagilova, Dwivedi, \& Slade, 2019). There is a need for culture as the moderator variable in generating results (Alrwashdeh et al., 2019; Nuseir, 2019). Cultural characteristics are divided into power distance, individualism/collectivism, masculinity, uncertainty avoidance, and long-term orientation (Hofstede, 1986). However, the researchers focus on the collectivist culture because previous studies indicate that Indonesian culture tends to be directed towards this cultural characteristic (Haryanto et al., 2016; Wijaya et al., 2018). For example, a region that has collectivist culture will interact a lot compared to individualism. Other people's opinions become very influential in the collectivist culture. Conversely, people who tend to be individualistic will pay less attention to others' opinions (Roberts, Jadalla, JonesOyefeso, Winslow, \& Taylor, 2017). Within the scope of a business, participation and user interaction are used to establish good company relationships. The cultural dimension of individualism/collectivism will significantly influence user behavior (Arpaci, Baloğlu, \& Kesici, 2018).

When there is recognition from other people on an excellent e-commerce brand, it will influence customers to purchase. It will strengthen and accelerate the growth of recognition of the quality of e-commerce (Atmojo, Budiastuti, Abbas, \& Kosala, 2019). Another previous research also proves that the collectivist culture in Indonesia strengthens the influence of relevant information about customer satisfaction with online purchases in e-commerce. A high collectivist culture affects Indonesian customers to be more tolerant about the lack of ease of use and guarantee of their privacy when making online purchases (Jauw \& Purwanto, 2017). In terms of e-commerce service providers, a good understanding of the characteristics of collectivist culture in Indonesia can help to meet customers' needs (Arinalhaq \& Widyanti, 2019). The culture between Indonesia and other countries may be different. Based on previous research limitations, it is necessary to add culture as a moderator by looking at positive experiences. Therefore, the other hypotheses are:

H6a: Culture moderates the relationship between customer satisfaction and purchase intention

H6b: Culture moderates the relationship between eWOM and purchase intention

H6c: Culture moderates the relationship between brand equity and purchase intention

The research proposes a model to examine the involvement of eWOM in e-commerce by looking at cultural factors as the moderating variable. Hence, it can influence purchase intentions through a theory of reason action and involve brand equity. This model shows that eWOM marketing communication looks at it from the perspective of forming its eWOM and variables to explain eWOM phenomena in e-commerce. Figure 1 shows the research model.

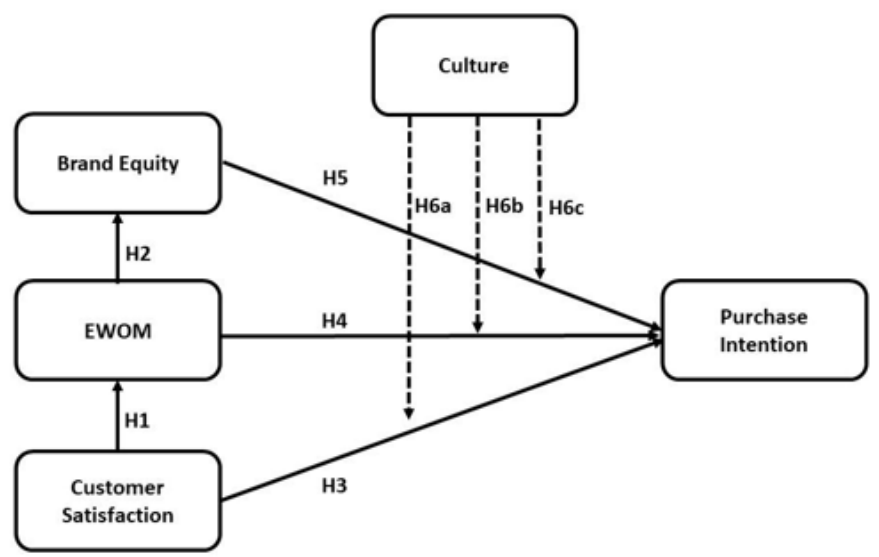

Figure 1 Research Model 


\section{METHODS}

The quantitative approach is applied in analyzing the obtained statistical data from 280 respondents. They are selected by non-probability sampling. The respondents are customers who have already bought products through e-commerce in Indonesia. The data collection through questionnaires uses Likert scale measurement from one (strongly disagree) to five (strongly agree). The questionnaire instrument is adopted based on theories from the previous researchers, such as satisfaction (Hew, Lee, Ooi, \& Lin, 2016), eWOM (Sijoria et al., 2019), brand equity (Beig \& Nika, 2019), culture (Nguyen, Lobo, \& Greenland, 2017; Sreen, Purbey, \& Sadarangani, 2018), and purchase intention (Akar \& Dalgic, 2018; Chiu, Kim, \& Won, 2018).

The Partial Least Square - Structural Equation Modeling (PLS-SEM) is used to validate the research model. This method is chosen because of its ability to test the relationship between the most comprehensive constructs with many measurement items (Henseler, 2017). There are two steps to evaluate the model in PLS-SEM. First, the researchers examine measurement models, such as reliability, convergent validity, and discriminant validity. Second, the researchers look at the explanatory value of the model, focus on the significance and relevance of the path coefficients, and examine the structural model (Sarstedt \& Cheah, 2019).

\section{RESULTS AND DISCUSSIONS}

Table 1 The Demographics of Respondents

\begin{tabular}{llc}
\hline & Category & Total \\
\hline \multirow{2}{*}{ Gender } & Male & 90 \\
& Female & 190 \\
& 17-25 years & 226 \\
Age & 26-35 years & 35 \\
& 36-45 years & 14 \\
& $>$ 46 years & 5 \\
Education & Senior high school & 205 \\
& Bachelor degree & 37 \\
& Master degree & 38 \\
& Lazada & 10 \\
E-commerce & Bukalapak & 9 \\
& Shopee & 137 \\
& Tokopedia & 124 \\
\hline
\end{tabular}

Data in Table 1 are collected by taking various characteristics of the respondents. Based on the result, there are more female respondents than that male. Women tend to shop through e-commerce. Moreover, the respondents are dominated by millennials (17 to 25 years) who have graduated from high school. The data also show that the dominating e-commerce brand is Shopee. It is in line with the data presented by iPrice (2020), stating that Shopee was in the top rank in 2020.

The reliability and validity of the model are tested to see Cronbach's alpha, Average Variance Extracted (AVE), and composite reliability. Convergent validity shows that the various observed variables from one latent construct are related to each other. The results can be seen in Table 2. According to the required value, all constructs have good values with higher AVE and composite reliability than 0,50 and 0,70 , respectively. Cronbach's alpha values range from 0,775 to 1,000 . It indicates that all constructs have good results because they are higher than the recommended Cronbach's alpha with a minimum of 0,7 (Hair, Risher, Sarstedt, \& Ringle, 2019).

Evaluation models are examined and have good results in reliability and validity. The regression analysis estimates the relationship between constructs. The researchers examine the direct effects of independent, dependent, and moderator variables. To test the structural models and hypotheses, the researchers use SmartPLS version 3.0. In Table 3 (see Appendices), the results of the relationship between variables are explained. The items have a good measurement because they match the required value $(>0,7)$.

Table 2 The Result of Reliability and Validity Tests

\begin{tabular}{lccc}
\hline Construct & $\begin{array}{c}\text { Cronbach's } \\
\text { Alpha }\end{array}$ & $\begin{array}{c}\text { Composite } \\
\text { Reliability }\end{array}$ & AVE \\
\hline Brand Equity & 0,940 & 0,947 & 0,563 \\
Culture & 0,771 & 0,845 & 0,523 \\
$\begin{array}{l}\text { Purchase } \\
\text { Intention }\end{array}$ & 0,856 & 0,891 & 0,541 \\
$\begin{array}{l}\text { Moderator } \\
\text { Effect 1 }\end{array}$ & 1,000 & 1,000 & 1,000 \\
$\begin{array}{l}\text { Moderator } \\
\text { Effect 2 }\end{array}$ & 1,000 & 1,000 & 1,000 \\
$\begin{array}{l}\text { Moderator } \\
\text { Effect 3 }\end{array}$ & 1,000 & 1,000 & 1,000 \\
$\begin{array}{l}\text { Customer } \\
\text { Satisfaction }\end{array}$ & 0,755 & 0,843 & 0,554 \\
EWOM & 0,963 & 0,966 & 0,539 \\
\hline
\end{tabular}

The results will show a significant direct effect if the t-value is higher than 1,96 , and the $\mathrm{p}$-value is smaller than 0,05. Table 4 (see Appendices) shows the results of the hypothesis test. H1 predicts the effect of customer satisfaction on the formation of eWOM. Customer satisfaction significantly influences eWOM with t-value of 24,305 and $p$-value of 0,000 . H1 is accepted. There is consistency with previous research models based on satisfaction (Leung, 2020; Sijoria et al., 2019). Companies must encourage customers to talk about their satisfying experiences (Anastasiei \& Dospinescu, 2019). 
For $\mathrm{H} 2$, it is regarding the effect of eWOM on brand equity. EWOM significantly influences the increase in brand equity with the t-value of 39,848 and the p-value of $0,000 . \mathrm{H} 2$ is accepted. These results support previous research, which states a significant relationship between the two variables. When there is positive eWOM, there will be an increase in a brand image (Aslam et al., 2019; Godey et al., 2016; Sijoria et al., 2019).

In $\mathrm{H} 3$, it predicts the effect of customer satisfaction on purchase intention. The result shows the t-value of 2,259 and the p-value of 0,024 . It implies that customer satisfaction significantly affects purchase intention. H3 is accepted. The result supports the previous research by (Bulut, 2015; Tandon et al., 2020). When customers are satisfied with the e-commerce website in making a purchase, their purchase intentions will increase. Customers are satisfied when e-commerce can be trusted and respond to their messages and complaints quickly. E-commerce should give a good impression and satisfy the customers. Meanwhile, the result is not significant in H6a, which predicts that the relationship of customer satisfaction and purchase intention moderated by culture. The result shows path coefficients of 0,443 . In Table 4 (see Appendices), it illustrates the insignificant relationship. The $\mathrm{p}$-value of 0,658 is higher than 0,05 . Thus, H6a is not supported.

Moreover, $\mathrm{H} 4$ predicts the effect of eWOM on purchase intention. The results show that eWOM has a significant effect on customer purchase intention. It is with the t-value of 2,245 and the p-value of 0,025 . The result is in line with the previous research, which shows that customers with a strong affinity for positive eWOM will tend to have a greater repurchase intention (Aslam et al., 2019; Yusuf et al., 2018). Meanwhile, in $\mathrm{H} 6 \mathrm{~b}$, it has an irrelevant result with the t-value of 1,423 and the p-value of 0,155 . It cannot predict the relationship of eWOM and purchase intention moderated by culture. H6b is rejected.

Next, H5 predicts the effect of brand equity on purchase intention. The result shows a significant effect of brand equity on purchase intention. It is with the t-value of 5,237 and the p-value of 0,000. The result is similar to previous research (Chiu \& Cho, 2019; Febrian \& Vinahapsari, 2020; Lee, Siu, \& Zhang, 2020). The higher the value of a brand is, the easier it will be to influence customers in the attitude towards the brand. For H6c, the result is not significant, with the t-value of 1,171 and the p-value of 0,242 . It cannot show the relationship of brand equity and purchase intention moderated by culture. H6c is not supported.

The results find that all independent variables have a significant influence on the dependent variable. Culture as the moderator variable can not get significant results in the relationship between all the variables. However, it can directly affect purchase intention. The research has the same results from previous research, which states that culture cannot be used as a moderator variable (Lee, 2017).

Table 5 (see Appendices) shows a grouping of results from the moderator variable (Sharma, Durand, \& Gur-Arie, 1981). In the first category, there are no interactions with the independent variable. However, there is an interaction with the dependent variable. This category has an additional predictor, intervening, exogenous, antecedent, or suppressor variable. The second category explains that there is no interaction with the independent and dependent variables. It is called homologies moderator. In the third category, there is a relationship between the two variables. It is called a quasi moderator. The fourth category explains that there is no relationship to the dependent variables. However, there is a relationship to the independent variables. It is called a pure moderator. Related to the moderator value results, although there are insignificant values of the culture as the moderator, it as a variable has a significant $p$-value of 0,000 . Then, culture can be an intervening, exogenous, antecedent, suppressor, or predictor variable in the relationship.

From a theoretical perspective, the research has produced some progress. First, it is related to a holistic approach to online shopping in e-commerce. It integrates several theoretical models that can be used to study consumer behavior. Furthermore, the research shows the complexity of several integrated theories into effective communication by adding relevant constructs so that eWOM becomes an essential predictor of shopping attitudes in e-commerce. Each dimension in forming a variable contributes well to what is discussed in the literature.

Second, in general, the variable that functions as a moderator can be seen from the extent to which it can explain the relationship between independent and dependent variables. The culture as the moderator variable gets irrelevant results in connecting independent and dependent variables. However, it has a significant value on purchase intention. It does not act as a moderator in the context of online purchases. It can be an exogenous variable that directly influences purchase intention. The research seeks to meet previous research limitations, which states that culture is needed by looking at marketing strategies comprehensively (Alrwashdeh et al., 2019; Ismagilova et al., 2020; Nuseir, 2019). The results state that culture can be used as an independent or exogenous variable in online purchase studies. These results are supported by previous research that the collectivist culture, which considers the opinions of others in making decisions, can be an antecedent variable to purchase intention (Aliyev \& Wagner, 2018; RosilloDíaz, Blanco-Encomienda, \& Crespo-Almendros, 2019; Watanabe, Torres, \& Alfinito, 2019).

For practical implication, online shopping is massive in the digital era, which makes e-commerce companies have to be superior to their competitors. Customer satisfaction is the companies' primary goal because it increases the repurchase intention. It can also influence customers to recommend the products to others through social media and features provided by e-commerce. It is beneficial for increasing the companies' brand equity. EWOM communication 
strategy is proven to affect purchase intentions because customers trust the stories of other customers who have shopping experience in e-commerce compared to provided information by the companies. Before making a purchase, the customers tend to see other customers' reviews regarding the same product in e-commerce. In the end, the research looks at the process when customers get reliable information. They will be involved in the formation of eWOM by sharing information and finding information through eWOM. Companies must encourage more customers to do eWOM to build brand credibility.

Another exciting result is the need for the addition of cultural factors in seeing an effective marketing strategy. The research focuses on the collectivist culture in Indonesia. E-commerce companies must consider cultural factors in influencing purchase intentions because each country has a different culture. Hence, it will also differ in how to approach it. The collectivist culture dimension can be the company's new focus in establishing communication between buyers and sellers in Indonesia. In a collectivist culture, customers are more easily influenced by others who become figures in the community. It will be an appropriate strategy for companies to use these figures as an eWOM communication tool.

\section{CONCLUSIONS}

The research focuses on the effect of customer satisfaction with eWOM and brand equity on increasing purchase intention by adding culture as the moderator variables. The researchers find that all independent variables have a significant influence on the dependent variable. However, culture as the moderator variable can not get significant results in the relationship between all the variables. On the contrary, it can directly affect purchase intention.

Although the research finds in-depth results on marketing theory, it has three limitations. First, in sampling, the research does not look at age differences, considering that not only young customers are shopping online, but also from some age groups. Then, the age factor or cohort generation can be used as a reference in selecting respondents for further research. Second, the research only uses collectivist culture factors in Indonesia. It may have different results if it is applied in collectivist culture in other countries. To generalize the findings, the researchers recommend the future researchers to compare the results with other countries having similarities with Indonesia. The research states that culture can be used as an independent variable in influencing purchase intention. Then, it can be used for further research. Third, because of Indonesia's cultural trends, public figures greatly influence purchase intentions. For further research, celebrity endorsement variable can be used to support the marketing of eWOM.

\section{ACKNOWLEDGMENTS}

The research was supported by Universitas Teknokrat Indonesia, which provided insight and expertise that greatly assisted the research, and the Ministry of Research Technology and Higher Education of the Republic of Indonesia, which helped the research fund.

\section{REFERENCES}

Ajzen, I. (1985). From intentions to actions: A theory of planned behavior. In Action control (pp. 11-39). Springer.

Akar, E., \& Dalgic, T. (2018). Understanding online consumers' purchase intentions: A contribution from social network theory. Behaviour and Information Technology, 37(5), 473-487. https://doi.org/10.1080/ 0144929X.2018.1456563

Al-Dwairi, R., Harb, Y., \& Shehabat, I. (2020). The role of social platforms in establishing brand awareness for B2C e-commerce: Empirical study. International Journal of Business Information Systems (IJBIS), 33(4), 488-504. https://doi.org/10.1504/ IJBIS.2020.105835

Aliyev, F., \& Wagner, R. (2018). Cultural influence on luxury value perceptions: Collectivist vs. individualist luxury perceptions. Journal of International Consumer Marketing, 30(3), 158-172. https://doi.or $\mathrm{g} / 10.1080 / 08961530.2017 .1381872$

Alrwashdeh, M., Emeagwali, O. L., \& Aljuhmani, H. Y. (2019). The effect of electronic word of mouth communication on purchase intention and brand image: An applicant smartphone brands in North Cyprus. Management Science Letters, 9(4), 505518. https://doi.org/10.5267/j.msl.2019.1.011

Amaro, S., \& Duarte, P. (2015). An integrative model of consumers' intentions to purchase travel online. Tourism Management, 46(February), 64-79. https:// doi.org/10.1016/j.tourman.2014.06.006

Anastasiei, B., \& Dospinescu, N. (2019). Electronic wordof-mouth for online retailers: Predictors of volume and valence. Sustainability, 11(3), 1-18. https://doi. org/10.3390/su11030814

Arinalhaq, F., \& Widyanti, A. (2019). The role of national culture on the design and usability of e-commerce websites: An Indonesian case. Journal of Physics: Conference Series, 1175, 1-8. https://doi. org/10.1088/1742-6596/1175/1/012192

Arpaci, I., Baloğlu, M., \& Kesici, Ş. (2018). The relationship among individual differences in individualismcollectivism, extraversion, and self-presentation. Personality and Individual Differences, 121, 89-92. https://doi.org/10.1016/j.paid.2017.09.034

Aslam, W., Farhat, K., \& Arif, I. (2019). Role of electronic word of mouth on purchase intention. International Journal of Business Information Systems (IJBIS), 30(4), 411-426. https://doi.org/10.1504/ ijbis.2019.10020633 
Atmojo, R. N. P., Budiastuti, D., Abbas, B. S., \& Kosala, R. (2019). The effect of e-WOM and structural assurances mediated by guanxi towards customer behavioral loyalty. Pertanika Journal of Social Sciences \& Humanities, 27(3), 1593-1607.

Azemi, Y., Ozuem, W., \& Howell, K. E. (2020). The effects of online negative word-of-mouth on dissatisfied customers: A frustration-aggression perspective. Psychology and Marketing, 37(4), 564-577. https:// doi.org/10.1002/mar.21326

Bae, S., Jung, T. H., Moorhouse, N., Suh, M., \& Kwon, O. (2020). The influence of mixed reality on satisfaction and brand loyalty in cultural heritage attractions: A brand equity perspective. Sustainability, 12(7), 1-22. https://doi.org/10.3390/su12072956

Beig, F. A., \& Nika, F. A. (2019). Impact of brand experience on brand equity of online shopping portals: A study of select e-commerce sites in the state of Jammu and Kashmir. Global Business Review, 1-20. https://doi. org/10.1177/0972150919836041

Bhattacherjee, A. (2001). Understanding information systems continuance: An expectation-confirmation model. MIS Quarterly, 25(3), 351-370. https://doi. org/10.2307/3250921

Bulut, Z. A. (2015). Determinants of repurchase intention in online shopping: A Turkish consumer's perspective. International Journal of Business and Social Science, 6(10), 55-63.

Cheng, B. L., Gan, C. C., Imrie, B. C., \& Mansori, S. (2018). Service recovery, customer satisfaction and customer loyalty: Evidence from Malaysia's hotel industry. International Journal of Quality and Service Sciences, 11(2), 187-203. https://doi. org/10.1108/IJQSS-09-2017-0081

Chiu, W., \& Cho, H. (2019). E-commerce brand: The effect of perceived brand leadership on consumers' satisfaction and repurchase intention on e-commerce websites. Asia Pacific Journal of Marketing and Logistics, ahead-of-print. https://doi.org/10.1108/ APJML-10-2018-0403

Chiu, W., Kim, T., \& Won, D. (2018). Predicting consumers' intention to purchase sporting goods online: An application of the model of goal-directed behavior. Asia Pacific Journal of Marketing and Logistics, 30(2), 333-351. https://doi.org/10.1108/ APJML-02-2017-0028

Civelek, M. E., \& Ertemel, A. V. (2019). The role of brand equity and perceived value for stimulating purchase intention in $\mathrm{B} 2 \mathrm{C}$ e-commerce web sites. Business and Economics Research Journal, 10(1), 233-243. https://doi.org/10.20409/berj.2019.165

Febrian, A., \& Vinahapsari, C. A. (2020). Brand equity is mediated in influencing purchase intentions on $\mathrm{e}$ commerce. TEST Engineering and Management, 82, 3703-3710

Fu, J. R., Ju, P. H., \& Hsu, C. W. (2015). Understanding why consumers engage in electronic word-of-mouth communication: Perspectives from theory of planned behavior and justice theory. Electronic Commerce Research and Applications, 14(6), 616-630. https:// doi.org/10.1016/j.elerap.2015.09.003
Godey, B., Manthiou, A., Pederzoli, D., Rokka, J., Aiello, G., Donvito, R., \& Singh, R. (2016). Social media marketing efforts of luxury brands: Influence on brand equity and consumer behavior. Journal of Business Research, 69(12), 5833-5841. https://doi. org/10.1016/j.jbusres.2016.04.181

Hair, J. F., Risher, J. J., Sarstedt, M., \& Ringle, C. M. (2019). When to use and how to report the results of PLS-SEM. European Business Review, 31(1), 2-24. https://doi.org/10.1108/EBR-11-2018-0203

Haryanto, J. O., Moutinho, L., \& Coelho, A. (2016). Is brand loyalty really present in the children's market? A comparative study from Indonesia, Portugal, and Brazil. Journal of Business Research, 69(10), 40204032. https://doi.org/10.1016/j.jbusres.2016.06.013

Hennig-Thurau, T., \& Klee, A. (1997). The impact of customer satisfaction and relationship quality on customer retention: A critical reassessment and model development. Psychology \& Marketing, 14(8), 737-764. https://doi.org/10.1002/(SICI)15206793(199712)14:8<737::AID-MAR2>3.0.CO;2-F

Henseler, J. (2017). Partial Least Squares path modeling. In Advanced Methods for Modeling Markets (pp. 361381). Cham: Springer International Publishing AG.

Hew, J. J., Lee, V. H., Ooi, K. B., \& Lin, B. (2016). Mobile social commerce: The booster for brand loyalty? Computers in Human Behavior, 59(June), 142-154. https://doi.org/10.1016/j.chb.2016.01.027

Hidayanto, A. N., Ovirza, M., Anggia, P., Budi, N. F. A., \& Phusavat, K. (2017). The roles of electronic word of mouth and information searching in the promotion of a new e-commerce strategy: A case of online group buying in Indonesia. Journal of Theoretical and Applied Electronic Commerce Research, 12(3), 69-85. https://doi.org/10.4067/ S0718-18762017000300006

Hofstede, G. (1986). Cultural differences in teaching and learning. International Journal of Intercultural Relations, $\quad 10(3), \quad 301-320 . \quad$ https://doi. org/10.1016/0147-1767(86)90015-5

Hult, G. T. M., Sharma, P. N., Morgeson, F. V., \& Zhang, Y. (2019). Antecedents and consequences of customer satisfaction: Do they differ across online and offline purchases? Journal of Retailing, 95(1), 10-23. https://doi.org/10.1016/j.jretai.2018.10.003

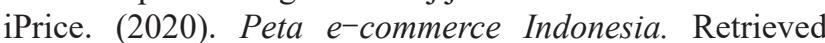
March $1^{\text {st }} 2020$ from https://iprice.co.id/insights/ mapofecommerce/

Ismagilova, E., Dwivedi, Y. K., \& Slade, E. (2019). Perceived helpfulness of eWOM: Emotions, fairness and rationality. Journal of Retailing and Consumer Services, 53(March), 1-56. https://doi.org/10.1016/j. jretconser.2019.02.002

Ismagilova, E., Slade, E. L., Rana, N. P., \& Dwivedi, Y. K. (2020). The effect of electronic word of mouth communications on intention to buy: A metaanalysis. Information Systems Frontiers, 22, 12031226. https://doi.org/10.1007/s10796-019-09924-y

Jauw, A. L. J., \& Purwanto, E. (2017). Moderation effects of cultural dimensions on the relationship between E-service quality and satisfaction with online 
purchase. Quality - Access to Success, 18(157), 5560.

Keller, K. L. (2020). Leveraging secondary associations to build brand equity: Theoretical perspectives and practical applications. International Journal of Advertising, 39(4), 448-465. https://doi.org/10.1080 /02650487.2019.1710973

Keller, K. L., \& Brexendorf, T. O. (2019). Measuring brand equity. In Handbuch Markenführung (pp. 14091439). Wiesbaden: Springer Gabler.

Krishnamurthy, A., \& Kumar, S. R. (2018). Electronic word-of-mouth and the brand image: Exploring the moderating role of involvement through a consumer expectations lens. Journal of Retailing and Consumer Services, 43(July), 149-156. https:// doi.org/10.1016/j.jretconser.2018.03.010

Lee, J. L. M., Siu, N. Y. M., \& Zhang, T. J. F. (2020). Does brand equity always work? A study of the moderating effect of justice perceptions and consumer attribution towards Chinese consumers. Journal of International Consumer Marketing, 32(1), 69-81. https://doi.org/1 0.1080/08961530.2019.1635551

Lee, M., Rodgers, S., \& Kim, M. (2009). Effects of valence and extremity of eWOM on attitude toward the brand and website. Journal of Current Issues and Research in Advertising, 31(2), 1-11. https://doi.org/10.1080/1 0641734.2009 .10505262

Lee, Y. K. (2017). A comparative study of green purchase intention between Korean and Chinese consumers: The moderating role of collectivism. Sustainability, 9(10), 1-17. https://doi.org/10.3390/su9101930

Leung, L. S. K. (2020). The impact of diurnal preferences on customer satisfaction, word of mouth and repurchasing: A study in Indian college online shoppers. Asia-Pacific Journal of Management Research and Innovation, 16(1), 21-30. https://doi. org/10.1177/2319510X19897455

Levy, S., \& Gvili, Y. (2020). Online shopper engagement in price negotiation: The roles of culture, involvement and eWOM. International Journal of Advertising, 39(2), 232-257. https://doi.org/10.1080/02650487.2 019.1612621

Liang, L. J., Choi, H. C., \& Joppe, M. (2018). Understanding repurchase intention of Airbnb consumers: Perceived authenticity, electronic word-of-mouth, and price sensitivity. Journal of Travel \& Tourism Marketing, 35(1), 73-89. https://doi.org/10.1080/10548408.201 6.1224750

Luo, C., Wu, J., Shi, Y., \& Xu, Y. (2014). The effects of individualism-collectivism cultural orientation on eWOM information. International Journal of Information Management, 34(4), 446-456. https:// doi.org/10.1016/j.ijinfomgt.2014.04.001

Nasiruddin, K. B., \& Hashim, H. B. (2015). Electronic word of mouth: Exploring consumer reactions and purchase intention. Journal of Global Business and Social Entrepreneurship, 1(1), 85-93.

Nguyen, T. N., Lobo, A., \& Greenland, S. (2017). The influence of cultural values on green purchase behaviour. Marketing Intelligence \& Planning, 35(3), 377-396. https://doi.org/10.1108/MIP-08-
2016-0131

Nuseir, M. T. (2019). The impact of electronic word of mouth (e-WOM) on the online purchase intention of consumers in the Islamic countries - A case of (UAE). Journal of Islamic Marketing, 10(3), 759767. https://doi.org/10.1108/JIMA-03-2018-0059

Oliveira, T., Alhinho, M., Rita, P., \& Dhillon, G. (2017). Modelling and testing consumer trust dimensions in e-commerce. Computers in Human Behavior, 71(June), 153-164. https://doi.org/10.1016/j. chb.2017.01.050

Olmedilla, M., Martínez-Torres, M. R., \& Toral, S. L. (2019). The superhit effect and long tail phenomenon in the context of electronic word of mouth. Decision Support Systems, 125(October). https://doi. org/10.1016/j.dss.2019.113120

Roberts, L. R., Jadalla, A., Jones-Oyefeso, V., Winslow, B., \& Taylor, E. J. (2017). Researching in collectivist cultures: Reflections and recommendations. Journal of Transcultural Nursing, 28(2), 137-143. https:// doi.org/10.1177/1043659615623331

Rosillo-Díaz, E., Blanco-Encomienda, F. J., \& CrespoAlmendros, E. (2019). A cross-cultural analysis of perceived product quality, perceived risk and purchase intention in e-commerce platforms. Journal of Enterprise Information Management, 33(1), 139160. https://doi.org/10.1108/JEIM-06-2019-0150

Sarstedt, M., \& Cheah, J. H. (2019). Partial Least Squares Structural Equation Modeling using SmartPLS: A software review. Journal of Marketing Analytics, 7, 196-202. https://doi.org/10.1057/s41270-01900058-3

Sharma, S., Durand, R. M., \& Gur-Arie, O. (1981). Identification and analysis of moderator variables. Journal of Marketing Research, 18(3), 291-300. https://doi.org/10.1177/002224378101800303

Shihab, M. R., \& Putri, A. P. (2019). Negative online reviews of popular products: Understanding the effects of review proportion and quality on consumers' attitude and intention to buy. Electronic Commerce Research, 19, 159-187. https://doi.org/10.1007/ s10660-018-9294-y

Sijoria, C., Mukherjee, S., \& Datta, B. (2019). Impact of the antecedents of electronic word of mouth on consumer based brand equity: A study on the hotel industry. Journal of Hospitality Marketing \& Management, 28(1), 1-27. https://doi.org/10.1080/1 9368623.2018.1497564

Sreen, N., Purbey, S., \& Sadarangani, P. (2018). Impact of culture, behavior and gender on green purchase intention. Journal of Retailing and Consumer Services, 41(March), 177-189. https://doi. org/10.1016/j.jretconser.2017.12.002

Tandon, A., Aakash, \& Aggarwal, A. G. (2020). Impact of EWOM, website quality, and product satisfaction on customer satisfaction and repurchase intention: moderating role of shipping and handling. International Journal of Systems Assurance Engineering and Management, 11, 349-356. https:// doi.org/10.1007/s13198-020-00954-3

Thakur, R. (2019). The moderating role of customer 
engagement experiences in customer satisfactionloyalty relationship. European Journal of Marketing, 53(7), 1278-1310. https://doi.org/10.1108/EJM-112017-0895

Turban, E., Whiteside, J., King, D., \& Outland, J. (2017). Introduction to electronic commerce and social commerce. Springer.

Valaei, N., Rezaei, S., Ismail, W. K. W., \& Oh, Y. M. (2016). The effect of culture on attitude towards online advertising and online brands: Applying Hofstede's cultural factors to internet marketing. International Journal of Internet Marketing and Advertising (IJIMA), 10(4), 270-301. https://doi.org/10.1504/ IJIMA.2016.081346

Watanabe, E. A. D. M., Torres, C. V., \& Alfinito, S. (2019). The impact of culture, evaluation of store image and satisfaction on purchase intention at supermarkets. Revista de Gestão, 26(3), 256-273. https://doi. org/10.1108/rege-12-2017-0009

Wijaya, S., Wahyudi, W., Kusuma, C. B., \& Sugianto, E. (2018). Travel motivation of Indonesian seniors in choosing destination overseas. International Journal of Culture, Tourism, and Hospitality Research, 12(2), 185-197. https://doi.org/10.1108/ IJCTHR-09-2017-0095

Yan, Q., Wu, S., Wang, L., Wu, P., Chen, H., \& Wei, G. (2016). E-WOM from e-commerce websites and social media: Which will consumers adopt? Electronic Commerce Research and Applications, 17(May-June), 62-73. https://doi.org/10.1016/j. elerap.2016.03.004

Yusuf, A. S., Che Hussin, A. R., \& Busalim, A. H. (2018). Influence of e-WOM engagement on consumer purchase intention in social commerce. Journal of Services Marketing, 32(4), 493-504. https://doi. org/10.1108/JSM-01-2017-0031

Zhang, H., Liang, X., \& Qi, C. (2021). Investigating the impact of interpersonal closeness and social status on electronic word-of-mouth effectiveness. Journal of Business Research, 130(June), 453-461. https:// doi.org/10.1016/j.jbusres.2020.01.020 


\section{APPENDICES}

Table 3 Instruments in the Questionnaire

\begin{tabular}{|c|c|c|}
\hline & Instruments & Outer Loading \\
\hline \multicolumn{3}{|c|}{ Customer Satisfaction } \\
\hline \multirow[t]{2}{*}{$\begin{array}{l}\text { Perceived usefulness (Hew } \\
\text { et al., 2016) }\end{array}$} & I find e-commerce useful in my life. & 0,805 \\
\hline & $\begin{array}{l}\text { Using e-commerce for purchasing enables me to discover the right } \\
\text { product at the right price. }\end{array}$ & 0,794 \\
\hline \multirow{2}{*}{$\begin{array}{l}\text { Confirmation } \\
\text { (Bhattacherjee, 2001) }\end{array}$} & My experience in using e-commerce is better than I expect. & 0,859 \\
\hline & The e-commerce service level is better than I expect. & 0,857 \\
\hline \multicolumn{3}{|c|}{ EWOM (Sijoria et al., 2019) } \\
\hline \multirow[t]{4}{*}{ Information quality } & Online information about e-commerce is relevant. & 0,746 \\
\hline & Online information about e-commerce is helpful. & 0,701 \\
\hline & Online information about e-commerce is clear. & 0,754 \\
\hline & Online information about e-commerce is logical. & 0,743 \\
\hline \multirow[t]{2}{*}{ Trust } & I trust online information about e-commerce. & 0,705 \\
\hline & I believe in online information about e-commerce. & 0,826 \\
\hline Loyalty & I write about e-commerce online when I am loyal to the e-commerce & 0,720 \\
\hline Satisfaction & $\begin{array}{l}\text { I share positive information about e-commerce when I have a good } \\
\text { experience with the received online information }\end{array}$ & 0,730 \\
\hline \multirow[t]{3}{*}{ Source quality } & $\begin{array}{l}\text { I think there is a social relation between the customers who share } \\
\text { online information about e-commerce. }\end{array}$ & 0,794 \\
\hline & I tend to associate with those who have similar interests like mine. & 0,778 \\
\hline & $\begin{array}{l}\text { I write about e-commerce to build new relationships via social } \\
\text { networks. }\end{array}$ & 0,737 \\
\hline Information quantity & $\begin{array}{l}\text { I see online reviews about e-commerce when the number of reviews } \\
\text { per product is many. }\end{array}$ & 0,739 \\
\hline \multirow[t]{3}{*}{ Subjective norm } & $\begin{array}{l}\text { I think my peers expect me to write/share my opinions about } \\
\text { different e-commerce. }\end{array}$ & 0,748 \\
\hline & $\begin{array}{l}\text { I think that people who are important to me write/ share my } \\
\text { opinions about different e-commerce. }\end{array}$ & 0,796 \\
\hline & $\begin{array}{l}\text { I think that people who are important to me expect me to write/share } \\
\text { my opinions about different e-commerce }\end{array}$ & 0,758 \\
\hline \multicolumn{3}{|c|}{ Brand Equity (Beig \& Nika, 2019) } \\
\hline \multirow[t]{3}{*}{ Brand association } & $\begin{array}{l}\text { I respect and admire people who shop from my favorite } \\
\text { e-commerce. }\end{array}$ & 0,721 \\
\hline & I like the brand image of my favorite e-commerce. & 0,767 \\
\hline & My favorite e-commerce is a customer-friendly company. & 0,809 \\
\hline \multirow[t]{4}{*}{ Brand perceive quality } & $\begin{array}{l}\text { I trust the quality of the products provided by my favorite } \\
\text { e-commerce. }\end{array}$ & 0,741 \\
\hline & $\begin{array}{l}\text { The products provided by my favorite e-commerce have good } \\
\text { quality. }\end{array}$ & 0,734 \\
\hline & My favorite e-commerce provides excellent services & 0,819 \\
\hline & The offered services by my favorite e-commerce are reliable. & 0,824 \\
\hline \multirow[t]{2}{*}{ Brand awareness } & $\begin{array}{l}\text { Some characteristics of my favorite e-commerce come to my mind } \\
\text { quickly }\end{array}$ & 0,751 \\
\hline & $\begin{array}{l}\text { I can quickly recognize my favorite e-commerce among other } \\
\text { e-commerce. }\end{array}$ & 0,791 \\
\hline \multirow[t]{2}{*}{ Brand loyalty } & I consider myself to be loyal to my favorite e-commerce. & 0,768 \\
\hline & I would love to recommend my favorite e-commerce to my friends. & 0,719 \\
\hline
\end{tabular}


Table 3 Instruments in the Questionnaire

(Continued)

\begin{tabular}{|c|c|c|}
\hline \multicolumn{3}{|c|}{ Culture } \\
\hline \multirow[t]{4}{*}{$\begin{array}{l}\text { Collectivist culture (Sreen } \\
\text { et al., 2018) }\end{array}$} & The well-being of my group members is important for me. & 0,767 \\
\hline & $\begin{array}{l}\text { Individuals should only pursue their goals after } \\
\text { considering the welfare of the group. }\end{array}$ & 0,704 \\
\hline & $\begin{array}{l}\text { Family members should stick together, even if they } \\
\text { disagree. }\end{array}$ & 0,711 \\
\hline & $\begin{array}{l}\text { I enjoy sharing items and spending time with my group } \\
\text { members. }\end{array}$ & 0,737 \\
\hline \multicolumn{3}{|c|}{ Purchase Intention (Chiu et al., 2018) } \\
\hline \multirow[t]{3}{*}{ Attitude } & I think that purchasing in e-commerce is good & 0,834 \\
\hline & I think that purchasing in e-commerce is wise & 0,770 \\
\hline & I think that purchasing in e-commerce is beneficial & 0,815 \\
\hline \multirow[t]{2}{*}{$\begin{array}{l}\text { Perceived behavioral } \\
\text { control }\end{array}$} & $\begin{array}{l}\text { Whether I purchase goods online in e-commerce or not, it } \\
\text { is entirely up to me }\end{array}$ & 0,753 \\
\hline & $\begin{array}{l}\text { I have enough resource (money or time) to purchase in } \\
\text { e-commerce }\end{array}$ & 0,713 \\
\hline Subjective norms & $\begin{array}{l}\text { Most people who are important to me recommend that I } \\
\text { purchase goods or services in e-commerce. }\end{array}$ & 0,721 \\
\hline
\end{tabular}

Table 4 Path Coefficients

\begin{tabular}{lcccc}
\hline & Hypothesis & $\begin{array}{c}\text { T-Statistics } \\
(|\mathbf{O} / \mathbf{S T D E V}|)\end{array}$ & P-Values & Result \\
\hline Customer Satisfaction $\rightarrow$ EWOM & H1 & 24,305 & 0,000 & Significant \\
EWOM $\rightarrow$ Brand Equity & H2 & 39,848 & 0,000 & Significant \\
Customer Satisfaction $\rightarrow$ Purchase Intention & H3 & 2,259 & 0,024 & Significant \\
EWOM $\rightarrow$ Purchase Intention & H4 & 2,245 & 0,025 & Significant \\
Brand Equity $\rightarrow$ Purchase Intention & H5 & 5,237 & 0,000 & Significant \\
Moderator Effect $1 \rightarrow$ Purchase Intention & H6a & 0,443 & 0,658 & \\
Moderator Effect $2 \rightarrow$ Purchase Intention & H6b & 1,423 & 0,155 & \\
Moderator Effect $3 \rightarrow$ Purchase Intention & H6c & 1,171 & 0,242 & \\
Culture $\rightarrow$ Purchase Intention & & 4,017 & 0,000 & Significant \\
\hline
\end{tabular}

Table 5 Specification Types of Moderator Variables

\begin{tabular}{lcc}
\hline & Related criterion and predictor & $\begin{array}{c}\text { Unrelated criterion and } \\
\text { predictor }\end{array}$ \\
\hline No interaction with predictor & 1 & 2 \\
& $\begin{array}{c}\text { exogenous, predictor, intervening, } \\
\text { antecedent, suppressor moderator }\end{array}$ & Homologies moderator \\
$\begin{array}{l}\text { Interaction with the predictor } \\
\text { variable }\end{array}$ & Quasi moderator & 4 \\
\hline
\end{tabular}

